\title{
MEDIA, MARGINS AND CIVIC AGENCY
}

\section{CHAPTER 3}

\section{"I wouldn't be a victim when it comes to being heard": Citizen journalism and civic inclusion}

Einar Thorsen, Daniel Jackson and Ann Luce

The UK political landscape has in recent years provided a particularly harsh backdrop of austerity and on-going cuts to welfare and disability benefits. In November 2014, for example, a 39-year-old woman who was unable to work due to chronic pain following two road traffic accidents took her own life. The Department of Work and Pensions (DWP) had sent several letters threatening to cut off her disability benefits and also demanded she pay back $£ 4,000$ already received. During the inquest into her death in March 2015, County coroner, Anne Pember, noted that she believed the "upset caused by the potential withdrawal of her benefits had been the trigger for her to end her life" (cited in Jones, 2015). According to Freedom of Information requests by the Disability News Network, the DWP had investigated some 49 cases where benefit claimants had died from February 2012 to February 2015 - 40 of these followed suicide or apparent suicide by the claimant, and 33 contained recommendations for improvements (Pring, 2015).

Those claiming disability benefits in the UK have also found themselves under attack from sections of the press - peddling, for example, 'cartoonish' depictions of disabled people as 'workshy scroungers' (Briant et al, 2011; Garthwaite, 2011; Slater, 2012). Time and again flawed or inaccurate reporting escape censure from an ineffective complaints and regulatory system. These media representations can be toxic for those on the receiving end, and compounds the challenges posed by the dismantling of the welfare state. Audience research meanwhile has found many people believed that the level of disability benefit fraud in the UK to be as high as $70 \%$ and worse, expressed support for the government position that many claimants did so as a lifestyle choice (Briant et al, 2011: 5).

If we accept that representation and understanding of their lifeworld is central to disability, then voice and access to the media become of paramount concern - as they hold the potential power to self-representation, which may challenge such mainstream narratives and political agendas. Marginalised groups have increasingly sought ways to engender new spaces - through, for example, citizen journalism - to articulate both their physical and discursive struggles to break down societal barriers. This chapter provides an analysis of one such citizen journalism project, initiated by a charity representing older and disabled people in the south of England. Through interviews and participant observation with the citizen journalists, we examine whether and how citizen journalism acts as a facilitator of citizen empowerment and a catalyst of social change. We explore their motivations and also the contradictory nature of citizen empowerment that was aroused by the project. Many of those interviewed highlighted the fear of publicly criticising the government as a genuine barrier, who felt vulnerable in the face of the government 'assault' on welfare and benefits. We nevertheless identify three distinct areas of empowerment experienced by the citizen journalists: community cohesion, civic inclusion, and accountability impact. 


\section{Representations of disability}

Disability can be considered as "fundamentally a struggle over 'representation"” (Williams, 1996: 194). Scholars have argued (e.g. Despouy, 1991; Swain and French, 2000) that the greatest barriers facing disabled people today are those of prejudice, discrimination and social isolation. Part of the reason for this has been attributed to the persistence of the discourse of the 'Medical Model' of disability which emphasises impairment as a 'problem' that is 'expertly' diagnosed and legitimated, and focuses on ways of 'fixing', or 'repairing', physical limitation (Barnes, Mercer and Shakespeare, 1999), as well as dominant media representations which perpetuate the 'Personal Tragedy model' that regards those with non-normative abilities as unfortunate victims; thus, depicting disabled people as "vulnerable", and "strange". Such discourses of "difference" produce a binary social relation of "Othering” i.e. "Us" and "Them" (Despouy, 1991). The 'Social Model', and more recently the 'Affirmative Model' of disability (see Swain and French, 2000) were in part a response by disability activists to the dominant media narratives. The adoption of the Social Model as an "organising principle" by disability groups has enabled a start to be made in transforming the social world in terms of the opportunities for disabled people to participate in everyday life (see Hodges et al., 2014). But as many studies have shown (e.g. Barnes 1992; Cumberbatch \& Negrine 1992; Shakespeare 1999), mainstream media representations have historically lagged behind the more progressive models of understanding disability and exclusion.

The relative lack of visibility of disabled people within the media has been well documented. Dominant media representations of disability have been criticised for being too simplistic, crude and one-dimensional (e.g. Cumberbatch \& Negrine 1992; Shakespeare 1999), reinforcing stereotypes of disabled people as weak (Ellis 2008; Wardle, Boyce \& Baron 2009), treating disability sports as little more than "human interest" (Berger 2008), and encouraging audiences to view athletes, actresses, television personalities and so on, through their impairment, rather than as people; thus erecting barriers to empathy and reinforcing a perceived distance between the audience and the objectified disabled character. Recent evidence from the UK suggests that progress has been made in terms of the quality and quantity of disabled representations on TV. Paralympians, for example, having become celebrities who are newsworthy for both positive and negative reasons (Claydon, Gunter and Reilly 2015), though such representations can be double edged when it comes to tackling certain societal prejudices (Molesworth, Jackson and Scullion 2015).

Alongside popular cultural representations of marginalised groups, the UK political landscape provides a harsh backdrop of austerity and on-going cuts to welfare and disability benefits. Those claiming disability benefits in the UK have found themselves under attack from sections of the press - peddling 'cartoonish' depictions of disabled people as 'workshy scroungers' (Briant et al, 2011; Garthwaite, 2011; Slater, 2012). Such media representations can be toxic for those on the receiving end. Related audience research has found many people believed that the level of disability benefit fraud in the UK to be as high as $70 \%$ and expressed support for the government position that many claimants did so as a lifestyle choice (Briant et al, 2011: 5).

If we accept that representation is central to disability, then voice and access to the media become of central concern, as they hold the potential power to self-representation, which may challenge such mainstream 
narratives. In the context of established media, the absence of disabled people in newsrooms and production studios has invariably lead to unbalanced coverage of disability issues (Goggin, 2009; Wardle, Boyce \& Baron 2009). Indeed it has been long established that ordinary citizens in general are only given limited access to and representation in media through (ideologically) constructed forms of 'public opinion' (see for example Lewis, 2001). This problem is further exacerbated when citizens are classed as marginalised by the dominant hegemony. Indeed the presence in media discourses of marginalised groups are frequently defined by health issues, where they are according to Campbell and Kerry (2011), “"spoken of” by health professionals and members of government rather than having the opportunities to speak for themselves". This perpetuates their social exclusion and undermines our understanding of their lived realities. Given slow progress on redressing these constructs, marginalised groups have increasingly sought alternative means to challenge their exclusion through different forms of citizen media, often combining social mobilisation with innovative participatory communication practices.

\section{Citizen journalism as agent for social change}

New and alternative media afford (at least in theory) different opportunities for marginalised groups to discuss, organise, self-represent and pursue political action. Citizen journalism literature, for example, has documented how hyperlocal initiatives often arise due to the "public's dissatisfaction with legacy media" and as an "attempt to fill the perceived gap in public affairs coverage" (Metzgar, Kurpius and Rowley, 2011: 782). Examples abound where disadvantaged or marginalised groups have adopted different forms of citizen journalism in this way to challenge their own civic exclusion - be that feminist movements, repressed indigenous people, or increasingly globalised social movements (Allan and Thorsen 2009, Thorsen and Allan 2014). In so doing they engender new spaces to articulate both their physical and discursive struggles to break down societal barriers. Viewed in this way, citizen journalism facilitates participatory forms of communication aimed at transformative social change, whilst at the same time energising the social cohesion of those marginalised groupings. This, according to Campbell and Kerry (2011: 270), is "dialogue and action that facilitate the development of confident and empowered identities". In their analysis of health communication, they found that:

"It [citizen journalism] also seeks to encourage members of excluded groups into dialogue about their health amongst themselves, as well as giving them a voice in public debates about how to tackle obstacles to their well-being, and involving them in efforts to challenge and renegotiate the way they are represented.” Campbell and Kerry (2011:277)

But as research on disability and new media has documented, there are many issues concerning access and accessibility (for example, exclusionary web design and unaffordable connection costs) that mean that online technology has often reproduced some of the environmental barriers that traditionally exclude disabled people from several aspects of social life (see Goggin and Newell, 2003; Vicente and Lopez, 2010). However, spurred on by the the climate of "emergency" created by the Coalition government's controversial plans for a welfare overhaul, there is a deep renewal in the structure, action repertoire and leadership of UK disability rights groups, and new media is at the heart of this revival (Trevisan 2013; 2015). Trevisan (2013) identifies the emergence of 
a new generation of technologically-savvy disabled "leaders", who are capitalising on their familiarity with new media to provide an alternative and un-mediated voice on disability issues.

Such important work is beginning to address the dearth of empirical work on the relationship between new media and disability activism. But it is largely focussed on "Digitised activists" (existing disability activists who appropriated new technologies in their activities) and "digital action networks" (online-only initiatives created and maintained by disabled bloggers-turned-activists with no prior experience of disability rights campaigning) (Trevisan, 2013; 2015). We know less about how "formal organisations" such as disability charities - whose primary function is often not about advocacy and activism but everyday needs - have adapted to the opportunities afforded by new technology. Moreover, we still know relatively little about the lived experiences of disabled activists in appropriating new technologies and online platforms, and the challenges and opportunities they face.

\section{Access Dorset TV}

Our entry point into these debates is the regional charity, Access Dorset, and their citizen journalism project ADTV. Based in Dorset on the South Coast of the UK, the organisation was formed in 2010 as a 'user led organisation' run by disabled people, older people and carers. Through its own membership and informal partnerships with 20 other like-minded organisations, Access Dorset currently incorporates over 4,000 people in the region. The organisation was established to help remove the physical, attitudinal, and community barriers faced in everyday life by its members. Central to this mission was the ability to participate in and influence public discourse on issues that affect them - a necessity that has only been intensified by the inimical political environment in the UK as Access Dorset CEO, Jonathan Waddington-Jones, explained:

With statutory services being cut and increasingly focused solely on those in most critical need, there are growing numbers of disabled people, older people and carers who are unable to access the support they need to live independently, healthily and with dignity. Many, whether in rural or urban areas, are isolated from peer support and lack opportunities for civic engagement (interview with authors, 2014).

For Access Dorset, citizen journalism was seen as a potential solution to these issues of peer support, civic engagement and public voice. ADTV was conceived in 2013 to overcome the challenges of exclusion, by creating a participatory platform of marginalised voices that can communicate direct to a diverse array of networked publics. Produced by and for its user-groups, ADTV (http://www.accessdorsetcentre.org) provides web-based peer support, information and lifestyle videos about their life experiences, events, social action projects and independent living.

The ADTV project consisted of an initial cohort of twelve citizen journalists. They were a mixture of disabled people and older non-disabled people. The disabled people had a range of hereditary and acquired disabilities, and all brought different challenges they are experiencing, as well as different emphases as to what they wanted to pursue in terms of story ideas. The group contained a number of people (approximately half) whose work had 
taken them into public life, such as a local councillor, community worker and disabled activist. Approximately half of them had some media experience, but as the subject of a story or as a source, not as producer.

Citizen journalism offers (at least in theory) an inherently empowering narrative, which can give voice to the voiceless in society and connect marginalised citizens to people within their communities. But we should not make assumptions about how members of a marginalised group experience it, nor should we overlook the many different forms in which citizen journalism is manifest. Our approach in this study was therefore to examine a citizen journalism initiative from the inside:

- what public issues they were concerned with, how they felt such issues are covered in the mainstream media, and their views of journalism;

- how they understand civic agency and empowerment, and how these are experienced through citizen journalism.

Findings presented here are based on approximately 20 hours of data collected from in-depth interviews with the twelve participants before and after a series of workshops we hosted. Each interview was audio-recorded and transcribed, then analysed by the authors. We also conducted more than 20 hours of participant observations of their experiences during the training and detailed analysis of their subsequent outputs. Our work was grounded in theoretical thematic analysis (Braun and Clarke 2006), meaning the analysis was influenced by the research questions (and indeed the literature review), but there was also an inductive element allowing for themes to evolve during the analysis process. In the following discussion, participants' names have been replaced by pseudonyms.

\section{Frustrations and motivations}

Participants in the Access Dorset TV project clearly represented different marginalised groups as described above, and they also had a vivid sense of their own social exclusion. Many talked openly about the 'social model' as a way of understanding and addressing social barriers, shifting the emphasis from their disability to barriers that they face - and crucially, stressing that those barriers could be removed. As such, these were not pacified and subdued individuals at some forgotten fringe, but rather a highly active and motivated group with a clear sense of purpose about challenging their marginalisation.

Through our initial work with the participants, we sought to explore the issues that were important to them and how they viewed the media reporting of these. All the participants described a sense of injustice about how Government funding had been cut under the auspice of austerity or made inaccessible through new assessment methods. Even where such policies did not directly affect them, they absorbed the perceived prejudice and some even took it personally as an affront to marginalised groups more generally. This came to the fore even more when the participants reflected on media coverage of disability issues. Frustration and even anger surfaced when they described how much of British media victimise and demonise people receiving benefits.

Because as I say with all the austerity measures that have been going on at the moment, with all benefits, the view of disability has slipped dramatically back down again. We are scroungers, we want 
this, we want that, we want everything, we want it now. But actually no, you get off your backside and go and get a job. You ever tried to get a job with a disability? It's virtually impossible, the discrimination that's there is more profound now than ever before because you're up against so many in the job market. (Terry, interview)

They were exercised not just by outright inaccuracy in reporting, but also sensationalism and lack of empathy. "They want the drama, they really do want the drama", Hannah said in reference to established media, "they don't want the good stories to come out which rubs off onto disabilities being a very negative lifestyle". Clearly disability is not a lifestyle choice, and yet this is the subtext in much of the reporting on the lived realities of disabled people - including the need to claim benefits in various forms. The discursive reduction of their illness was experienced by several as particularly demeaning - as Participant Hannah noted:

I don't see why we should be pushed and shoved, and this is because you do feel a very vulnerable person in society [...] When you're on a train and you're compared to a piece of luggage. (Hannah, interview)

Mary echoed a sentiment also expressed by others, arguing "media have a slanted view of disability" placing undue attention on those "people who abuse the system":

They make out that there are so many disabled people out there, making out that disabled people are getting all this money who shouldn't be. (Mary, interview)

Whilst she did not question the existence of benefit fraud per se, it was the generalised demonisation of a marginalised group as a whole that was problematic. Indeed the generalisation was a consequence not only of misguided or misleading terminology used in reporting, but also the inadequate attention placed on communicating the lifeworld of disabled peoples. "I don't think the press is very good at showing what living with a disability is really like day to day", she argued. This attention to expressing and communicating everyday lived realities of marginalised peoples was a major motivating factor in why they chose to pursue their own form of journalism through ADTV. In this way the participants were hoping to not only normalise their lifeworld, but also educate audiences about the barriers disabled people experience on a daily basis. Polly, who was paralysed from the chest down following a road traffic accident, expressed this poignantly in terms of offering alternative perspectives to raise awareness:

I think I would like to feel I am improving and enhancing people's lifestyles by offering not alternatives but perhaps a different thought pattern and changing perspective of those that haven't had to use a wheelchair or have got a disability. Just to sort of think outside of what their life is like for a second... I think for me because it happened so suddenly, I wouldn't want my today to be their tomorrow. Motivations - for others to see how disabled people live. Education. (Polly, interview)

For Access Dorset addressing such issues of representation and participation was at the core of the ADTV project. Indeed, their ambition was stated by some of the participants as an overt challenge to the political 
establishment - both locally and nationally. However, not everyone involved shared the same desire for activism. Instead they viewed participation in the project as a form of confidence building and way of networking with other marginalised people. In this way the ADTV project was also positioned as a vehicle to foster enhanced community cohesion. That is, bringing together people representing different marginalised groups (thus cohesion among the project participants), and also rendering visible their voices in the community so they could feel part of public life.

\section{Empowering marginalised voices}

From November 2013 to January 2014, the authors delivered a five-week intensive training course for these volunteers on foundation principles of video journalism - aimed at affording them the skills and confidence to develop the ADTV project alongside their other advice and support functions as charity workers. Outputs from the ADTV project had at the time of writing all been video based, with the variety of stories reflecting the different interests and motivations of the participants. Videos produced can broadly be classified as 1) information and lifestyle, 2) campaign and advocacy, and 3) reportage on marginalised issues. They have made videos about living with cancer, anorexia, emergency medical treatment for older people, inaccessible footpaths for disabled people, and overcoming attitudinal barriers to disability to name a few.

ADTV has evidently had a positive impact on the participating citizen journalists and their ability to vocalise concerns, even within its first year of operation. Three distinct areas of empowerment of participating citizens emerged through interviews we conducted during the project: community cohesion, civic inclusion, and accountability impact.

\section{Community cohesion of marginalised groups}

The notion of any kind of disabled 'community' existing writ large has always been problematic (see for e.g. Hodges et al. 2014), due not least to the challenges of public voice, media representation and social isolation. Access Dorset is an umbrella organisation for various local and regional charities. As it serves a wide geographical spread of users - often living at the margins of society - creating a sense of shared identity and community cohesion is often an acute challenge, yet it is a primary purpose of the charity. Community media be it for diasporas (see Ogunyemi, this volume), ethnic groups (e.g. Tsagarousianou 2001) or womens' movements (e.g. Isaacs-Martin, 2004) - offers the opportunity to produce content relevant to the lives of marginalised people, challenge dominant semiotics and give public voice through self representation. In terms of enhancing community cohesion, we found that this worked on two levels, related to both the inputs and outputs of the citizen journalism project.

At the input level, the journalism workshops brought together people with very different backgrounds, ages and disabilities. Of the twelve citizen journalists, three were full-time Access Dorset employees; the rest were volunteers of varying regularity. Therefore a number of them barely knew each other at the start of the training. By participating in the workshops they established new friendships, and strengthened their sense of shared 
purpose in an otherwise diverse and disparate organisation. So the process of developing a shared purpose and identity was empowering (see also Campbell and Kerry, 2011):

The other thing about the training, I thought, we've always had a very strong team ethos. I think some of us were initially concerned should we really all of us be involved in this, will it be cramping the style of volunteers in terms of learning. I think it quickly proved to be the right thing to do because it strengthened that team ethos, where we are all learning together [...] And certainly, I suppose,

following on from it and stuff, I am in awe of some of my colleagues and how quickly they've grasped some of the things (Peter, interview).

Like many other charities, Access Dorset exists on a small budget, and is reliant on a network of volunteers. These volunteers need to be motivated and committed, and feel like their work is valued. For our participants, taking part in the training had the effect of galvanising some of the volunteer members into becoming more engaged with the charity, thus increasing its capacity.

This galvanising effect on the organisations' members also came through the outputs of the project. As Peter explains, the charity has been able to strengthen its broader network and better represent its members through the project, with the use of video being crucial:

I think one of the things that we have found with all of this, we have really kicked in as an organisation. You look at the disabled organisations in the country, they tend to be of older people. It can often be difficult to involve younger people, they have different experiences than older people of the struggles around disability. So it can be difficult sometimes to attract and involve younger people. And particularly for an organisation like ourselves, working with people with learning disabilities, it can be difficult. How do you integrate with them without dumbing down what you are doing? What we found with ADTV and the whole approach was that young people want to make films. This is brilliant, what a great way to communicate and so we've made a number of films with people with learning disabilities who want to get involved and want to do more. So I think that alone has empowered us and made us stronger and a lot more confident as well. (Peter, interview)

\section{$\underline{\text { Giving people a voice: empowerment and civic inclusion }}$}

Of the twelve citizen journalists who undertook the training and pioneered the project, approximately half made it clear through the interviews that they did not consider themselves disempowered, voiceless, victims. At least three had had a career in public life in one way or another, and were used to speaking to those in power. As Polly explains,

I've got a pretty big mouth. I'm pretty good there. I would either say something myself or to say something more strongly like in the case of the town hall, I'd go to these guys. I'm pretty good like that. I wouldn't be a victim when it comes to being heard. (Polly, interview) 
But for the rest of the group of citizen journalists, the project brought them into the public sphere for the first time. For them, this was a transformative and empowering experience. The first emergent theme here was that gaining the technical competences of video journalism gave them new confidence, as Jennifer explains:

It's a lovely feeling. It's one of those things where I suppose my main skillset has never been on the technical side of anything and you watch the television, you look at a corporate film that someone's put together and you can't even imagine, I can't even imagine being involved in that or being able to do that. But it's a lovely feeling to know 'I know actually how you do it and I have a good understanding of how you did it and I could have a good go myself'. It is a very empowering feeling. And it has certainly boosted my confidence in realising that I have other competencies, rather than just the ones I know I've got. And if I had the time I feel pretty confident that I could learn more. (Jennifer, interview)

Jennifer was not the only participant to allude to an increased media literacy gained through becoming a practicing citizen journalist. Others too spoke of the way that they now watch TV and film in a new light, critically 'reading' both the technical aspects of media production, but also deconstructing its ideological biases; both useful competences for the rounded citizen (see Livingstone, Van Couvering and Thumin, 2005).

The seemingly inherent growth in individual confidence through the development of new skills was - we argue closely linked to a greater sense of collective voice as a disabled or older person, as Mary explains:

It's made me feel more empowered and it's given me more confidence as a person, to go out and do some filming and be proud of what I've done. [...] Whether I do it for someone else or on my own, I'm equally proud of it [...] But the whole thing has made Access Dorset more empowered to really take on the issues that affect all disabled people. Actually we're the best people to film them because we know about them. (Mary, interview)

For the Access Dorset citizen journalists, it was not only about gaining access to the modes of production, but making a difference by being different. Referring to professional journalists, Laura observed how "their motivations are completely different". As a self-identified citizen journalist, she valued their own "freedom", reporting on "issues that are directly affecting you on a local level, on a personal level and from the perspective of a person living everyday life rather than from the perspective of media trying to sell it". This is a significant point concerning how they conceived the importance of authentic (disabled) voices. As Mary explains, the broader hope is that inclusion means empowerment:

I think for the project its about [...] disabled people or older people within Access Dorset saying actually this is an issue we need to address and you are the best person to talk to. It's not right for us to come and do it for you if you can do it yourself or identify one of the team who are going to do it and it makes a difference. It puts it out there, makes people more aware of an issue or makes someone feel less isolated, you know, then that's successful. If people feel that they are in control of what they do 
themselves and have some control over it or some control to change it or put it out there than that's a good thing, it empowers people to do more for themselves. (Mary, interview)

Through the course of our interviews and observations it was clear that many of the citizen journalists spoke of their new-found empowerment, internal political efficacy and a strong sense that what they were doing would be empowering for others like them. But most were also aware that there are many real-world barriers for disabled people that their ADTV project was yet to overcome, which speaks directly to the contradictory nature of citizen empowerment. For instance, of all the barriers to having their voice heard we explored with interviewees, physical and mental impairment were virtually absent; but the fear of publicly criticising the government was a genuine barrier for many, who felt vulnerable in the face of the government 'assault' on welfare and benefits. "Historically in Dorset disabled people have been very passive because they are frightened they are going to lose their care", Terry commented, "so they've always remained not expressing any desire to challenge anything." Robert added, "This is typical of everybody out there, people are terrified. We're consumers of these [public] services. It's very difficult to be using them and criticizing them at the same time. So that's the barrier, a huge barrier." In working with such vulnerable and isolated people who have agreed to be filmed, the citizen journalists were acutely aware of treating their subjects with the necessary caution needed so as not to leave them exposed. Therefore, an important tension in this project was the way that the citizen journalism of ADTV spoke to power, which we unpack further below.

\section{$\underline{\text { Holding power to account and accelerating impact }}$}

Many of our participants were - as noted earlier - active, confident citizens, and through their work with Access Dorset had already campaigned on issues they care about. But the citizen journalism they pursued through ADTV appears to have elevated (if not transformed) their visibility to those in power, and hence their effectiveness at achieving policy changes. Specifically, the video format, and the publicness (through the web and social media) of ADTV was highlighted by several participants as appearing to have a more immediate impact than the traditional campaigns they had previously experienced. "I think in the journalism and in the filmmaking we found a medium that people are more interested in listening to", Jennifer commented. "Before, when we're talking about engaging and making ourselves heard, it's an email, it's a letter, it's a phone call [...] They (local government) get a lot of those. Making your point through a film and quite publicly has had impact multiple times." In other words, video based citizen journalism has enabled these marginalised groups to dramatically accelerate action on issues they campaign on.

One of the most high profile reports has been in support of their campaign to make a local railway station accessible for disabled people. The video and campaign has made local headlines, gained the support of local politicians, and has even been discussed in British Parliament. This is an overtly political video, supported by an e-petition (underneath the video), and headed by one of the most politically empowered members of the ADTV team. But it has a tone of voice which is characteristic of the type of relationship to power the organisation is trying to achieve, a point which was repeated several times amongst interviewees: 
somebody might say we've got an agenda but for example Poole and Bournemouth Council are not on the agenda, this is not what we're here for. It's not hitting the councils on the head with their mistakes. If you highlight a real issue and a good, positive way and you say: 'Are you aware of this? This is the problem it's causing. Are we going to be able to do something about it?' I think you're more likely to get something done. (Mary, interview)

The citizen journalists were thus acutely aware of not wanting to be a negative force, criticising the authorities from the sidelines and subsequently being ignored. A recurring theme of the journalism they produce, then, is to position themselves as an engaged, passionate advocacy group "who don't pull any punches" (Peter, Interview) in pointing out the failings of the authorities, but whom the authorities can also work with to make things better.

There is still an ongoing tension in this position though. For example, Access Dorset are now getting approached by the local council and other authorities to make films about accessibility on their behalf. This is obviously beneficial for accelerating impact and achieving their goals, but it also raises tensions over their role as an independent and critical voice from the authorities, as Jennifer explains:

It's scary because that's obviously not our roots and we're learning as we go as well but our unique selling point and what is attractive about us is that, obviously all the films that have been commissioned are from a user-led, disabled people angle, and that why we are different. All these people, BH Live and the council have used commercial companies before but they've decided they want to approach us because I think: 'Well, we've seen the films that they do, they are doing a good job but also on top of that they've got all the right contacts, they are selling it from the right angle' [...] That's the power of us and that I suppose we need to take forward, our unique selling point.

As we know from studies of pressure group politics, becoming an insider group can have many benefits for voice and influence, but can create tensions with the grassroots of an organisation who wish to remain at armslength to the powerful (see Grant, 2000). Our participants were well aware of this tension. To be able to respond to such commercial requests that may potentially conflict with the citizen journalism, Access Dorset are setting up a commercial filmmaking arm that tries to erect some distance between it and the ADTV project.

\section{Conclusion}

It seems clear that the political establishment in the UK is failing to adequately address the needs of marginalised groups on a number of levels, as exemplified at the outset of this chapter. Many vulnerable people are afraid of speaking up against social injustice - some in our study, for example, citing people with concerns about having their support systems eroded as a consequence. When established media perpetuate this anxiety through inaccurate reporting and misleading generalisations, it is little wonder that those who are marginalised seek alternative means to break through these societal barriers. Often expressed through different forms of citizen journalism or community media, ordinary people are making efforts to regain control over their own 
mediation and representation. Seeking, in other words, a sense of empowerment and civic agency through (self)communication.

ADTV is just one of many online citizen journalism projects that has surfaced over the past two decades in response to a perceived lack in public affairs reporting and as a way of mobilising ordinary people around shared causes. We found that the ADTV project was an effective focal point for Access Dorset to mobilise a core group of volunteers. Including disabled and older people in the production of online video also empowered people who are otherwise marginalised from both production of news and representation of issues that concern them. Participants in the ADTV project were given responsibilities and opportunities many of them thought they would never have experienced. Moreover, they were able to command a public platform for their voices and draw attention to their campaigns in ways they had not been able to do before. In so doing, otherwise marginalised people were able to put themselves at the centre of public debate - in a way that they felt comfortable with. Indeed the expression of their voices through a highly personalised, raw and often impressionistic video format was seen to accelerate attention from authorities and thus their ability to affect change.

It is evident from our research that the citizen journalists involved with ADTV experienced empowerment on a number of different levels. Whilst this is often a deeply personalised experience, their ability to enter and shape public debates should also have a tangible effect on lived experiences of others - be that through videos about home adaptations, triggering change to dropped curbs, or campaigns about public transport accessibility. What they do not, as yet, have a clear sense about it to what extent citizen journalism is empowering their broader constituency - that is, non-participating members or user-groups. However, what they do have is at least a mediated representation emanating from their own group that is helping to redefine what is meant by 'the centre'. Indeed as the famous saying from Shakespeare's Coriolanus goes: “The People Must Have Their Voices". ADTV shows how some disabled and elderly people have given themselves a public voice through citizen journalism. One that appears to be transforming them both as individuals and a collective force.

\section{References}

Allan, S. and Thorsen, E. (2009) Citizen Journalism: Global Perspectives, Volume One, New York: Peter Lang

Barnes, C. (1992) Disabling imagery: An exploration of media portrayals of disabled people, Halifax: Ryburn/ BCODP.

Barnes, C., Mercer, G. \& Shakespeare, T. (1999) Exploring Disability, A sociological introduction, Cambridge: Polity Press.

Berger, R. (2008) 'Disability and the dedicated wheelchair athlete', Journal of Contemporary Ethnography, 37(6), pp.647-678.

Briant, E., Watson, N. and Philo, G., (2011) Bad News for Disabled People: How the Newspapers are Reporting Disability. Glasgow, UK, Strathclyde Centre for Disability Research and Glasgow Media Unit: University of Glasgow. 
Campbell, C. and Scott, K. (2011) Mediated health campaigns: from information to social change. In: Hook, D., Franks, B. and Bauer, M.W., (eds.) Social Psychology of Communication. Palgrave Macmillan, Basingstoke, UK, pp. 266-284.

Claydon, A., Gunter, B. and Reilly, P. (2015) Dis/Enablement?: An Analysis of the Representation of Disability on British Terrestrial Television Pre- and Post- the Paralympics. In. D. Jackson, C. Hodges, R. Scullion, and M. Molesworth (eds.), Reframing disability? Media, (dis)empowerment and voice in the 2012 Paralympics, Routledge: London, pp. 37-65.

Cumberbatch, B. and Negrine, R. (1992) Images of Disability on Television, Routledge: London.

Despouy, L. (1991) Human Rights and Disability, United Nations E/CN.4/Sub.2/1991/31

Ellis, K. (2008) 'Beyond the Aww Factor: Human interest Profiles of Paralympians and the media navigation of physical difference and social stigma', Asia Pacific Media Educator, 19, pp. 23-35.

Garthwaite, K. (2011) “'The language of shirkers and scroungers?' Talking about illness, disability and coalition welfare reform', Disability \& Society, 26:3, 369-372.

Goggin, G. and Newell, C. (2003) Digital Disability: The Social Construction of Disability in New Media, Lanham: Rowan \& Littlefield.

Goggin, G. (2009) Disability, Media, and the Politics of Vulnerability. Asia Pacific Media Educator, 19, 2-1-213.

Grant, W. (2000) Pressure groups and British politics. Basingstoke: Palgrave Macmillan.

Hodges, C., Jackson, D., Scullion, R., Thompson, S. and Molesworth, M. (2014). Tracking changes in everyday experiences of disability and disability sport within the context of the 2012 London Paralympics. CMC Publications, Bournemouth University. Available from: https://microsites.bournemouth.ac.uk/cmc/files/2014/10/BU-2012-London-Paralympics.pdf (Accessed $11 / 02 / 2015)$.

Isaacs-Martin, W. (2008). (Re)creating gender identities in community media. Agenda: Empowering Women For Gender Equity, (77), 140.

Jones, C. (2015) 'Northampton woman, 39, took her own life after 'constant battle' to receive disability benefit', Northampton Chronicle \& Echo, 5 March, Available from:

http://www.northamptonchron.co.uk/news/northampton-woman-39-took-her-own-life-after-constantbattle-to-receive-disability-benefit-1-6615017 Accessed 08/03/2015

Lewis, J. (2001) Constructing public opinion: How political elites do what they like and why we seem to go along with it. Columbia University Press.

Livingstone, S., Van Couvering, E. and Thumin, N. (2005) Adult media literacy: A review of the research literature. OfCOM. Available from: http://stakeholders.ofcom.org.uk/binaries/research/medialiteracy/aml.pdf. Accessed 20/02/2014.

Metzgar, E., Kurpius, D., and Rowley, K., (2011) "Defining hyperlocal media: Proposing a framework for discussion", New Media \& Society, Vol 13 No 5.

Molesworth, M., Jackson, D. and Scullion, R. (2015) 'Where Agendas Collide: Online Talk and the Paralympics'. In. D. Jackson, C. Hodges, R. Scullion, and M. Molesworth (eds.), Reframing disability? Media, (dis)empowerment and voice in the 2012 Paralympics, Routledge: London, pp. 123-137. 
Peers, D (2012) 'Interrogating disability: The (de)composition of a recovering Paralympian', Qualitative

Research in Sport, Exercise and Health, 4(2), pp. 175-188, Online, Available HTTPS <

http://www.tandfonline.com/10.1080/2159676X.2012.685101> (accessed 11/09/2014).

Pring, J. (2015) 'Secret DWP reviews called for improvements after benefit deaths', Disability News Service, 6

March, Available from: http://www.disabilitynewsservice.com/secret-dwp-reviews-called-for-

improvements-after-benefit-deaths/ Accessed 08/03/2015

Shakespeare, T. (1999) 'Art and lies? Representations of disability on film', in Corker, M. \& French, S. (eds.)

Disability discourse, Buckingham: Open University Press, pp. 164-172.

Slater, J. (2012) 'Stepping outside normative neoliberal discourse: youth and disability meet - the case of Jody

McIntyre', Disability \& Society, 27:5, 723-727.

Swain, J. \& French, S. (2000) 'Towards an affirmative model of disability’, Disability and Society, 15(4), pp. 569-582.

Thorsen, E. and Allan, S. (2014) Citizen Journalism: Global Perspectives, Volume Two, New York: Peter Lang.

Trevisan, F. (2013) “Disabled People, Digital Campaigns, and Contentious Politics: Upload Successful or Connection Failed?,” in Scullion, R., Lilleker, D., Jackson, D., and Gerodimos, R., (Eds.), The Media, Political Participation, and Empowerment, London: Routledge, pp. 175-191.

Trevisan, F. (2015) "Contentious Disability Politics on the World Stage: Protest at the 2012 London

Paralympics," in Jackson, D., Molesworth, M., and Scullion, R. (Eds.), Reframing Disability? Media,

(Dis)empowerment and Voice in the 2012 Paralympics, London: Routledge, pp. 154-171.

Tsagarousianou, R. (2001) "Ethnic community media, community identity and citizenship in contemporary

Britain”. In: Jankowski, N. and Prehn, O. (eds.) Community media in the information age: perspectives and prospects. Hampton Press, Cresskill, USA, 209-230

Vicente, M. and Lopez, A. (2010) 'A Multidimentional Analysis of the Disability Digital Divide: Some

Evidence for Internet Use,' The Information Society, 26(1): 48-64.

Wardle, C, \& Boyce, T. \& Barron, J. (2009) 'Media coverage and audience reception of people with disfigurement or visible loss of function', The Healing Foundation, Online, Available HTTPS:

$<$ http://www.cardiff.ac.uk/jomec/resources/09mediacoverageofdisfigurement.pdf $>$ (accessed 16/05/2013).

Williams, G. (1996) 'Representing Disability: Some Questions of Phenomenology and Politics', in Barnes C. \& Mercer, G. (eds.) Exploring the Divide, Leeds: The Disability Press, pp. 194-212.

\footnotetext{
${ }^{\mathrm{i}}$ The Social Model of disability advocates that disability is socially-constructed and, therefore, a consequence of the way society is organised, rather than an individual's impairment or difference.
} 